\title{
Artichoke leaf extracts: Proteolytic activity, coagulant and HPLC analysis
}

\author{
Extratos das folhas da alcachofra: Atividade proteolítica, \\ coagulante e análise por HPLC
}

\author{
Gabriela Muricy de Souza Silva ${ }^{1 *}$ (D) , Jessyka Silva da $\operatorname{Costa}^{1}$ (D) , Janaina Oliveira Freire ${ }^{1}$ (D), \\ Leandro Soares Santos ${ }^{1}$ (D), Renata Cristina Ferreira Bonomo ${ }^{1}$ (D)
}

\author{
'Universidade Estadual do Sudoeste da Bahia/UESB, Itapetinga, BA, Brasil \\ *Corresponding author: gabrielamuricy26@hotmail.com \\ Received in January 31, 2021 and approved in May 7, 2021
}

\begin{abstract}
The search for origin plant-based proteases increases gradually due to their diversity and stability over a wide range of $\mathrm{pH}$ and temperature. Artichoke (Cynara scolymus) flowers are a proteolytic vegetable source already studied, but their leaves are scarce in this respect. Thus, the objective of this research was to obtain extracts of artichoke leaves with different buffers and extraction methods as an alternative proteolytic source and plant coagulant, as well as the separation and comparison of the protein profile of these extracts. The methodology used was based on extraction with sodium citrate buffer $(\mathrm{pH} 3)$, sodium acetate $(\mathrm{pH} 5)$ and Tris- $\mathrm{HCl}(\mathrm{pH} 7)$ by mechanical stirrer (MS) and ultrasound (US); protein determination; proteolytic activity (PA) and specific activity (SA); milk clotting activity (MCA) and rennet substitution potential (RSP); high- performance liquid chromatography analysis (HPLC) with UV-Vis detector and principal component analysis (PCA). Extracts of Cynara scolymus leaves showed high results with Citrate-US for the parameters PA (14.38), SA (19.71), MCA (440) and RSP (30.60) compared to other treatments. The extracts with citrate and acetate presented a quick coagulation time ( $\max 3 \mathrm{~min}$ ). The HPLC analysis enabled the separation of the different protein compounds present in the extracts and most expressive peaks in the samples with Citrate-MS and Acetate-MS; and isolated peaks for Citrate-US. It was concluded that extracts of artichoke leaves with citrate and acetate buffer attributed satisfactory results to act as plant coagulant, as well as to carry out further studies for the purification of proteolytic enzymes and application in cheeses.
\end{abstract}

Index terms: Extraction methods; protein compounds; chromatography; principal component analysis; Cynara scolymus.

\begin{abstract}
RESUMO
A busca por proteases de origem vegetal aumenta gradualmente devido à sua diversidade e estabilidade em ampla faixa de $\mathrm{pH}$ e temperatura. As flores da alcachofra são uma fonte vegetal proteolítica já estudada, porém suas folhas são escassas nesse aspecto. Assim, o objetivo dessa pesquisa foi a obtenção de extratos das folhas da alcachofra com diferentes tampões e métodos de extração como fonte alternativa proteolítica e coagulante vegetal, bem como a separação e comparação do perfil proteico desses extratos. A metodologia utilizada foi baseada na extração com tampão de citrato de sódio (pH 3), acetato de sódio (pH 5) e tris- $\mathrm{HCl}(\mathrm{pH} 7)$, por agitação mecânica (AM) e ultrassom (US); determinação de proteínas; atividade proteolítica (AP) e atividade específica (AE); atividade de coagulação do leite (ACL) e potencial de substituição do coalho (PSC); análise de cromatografia liquida de alta eficiência (HPLC) com detector UV-Vis e análise de componentes principais (ACP). Os extratos das folhas Cynara scolymus apresentaram resultados elevados no extrato com Citrato-US para os parâmetros AP $(14,38)$, AE $(19,71)$, ACL $(440)$ e PSC $(30,60)$ comparados aos demais tratamentos. Os extratos com citrato e acetato tiveram tempo de coagulação rápido (máx $3 \mathrm{~min}$ ). A análise de HPLC possibilitou a separação dos diferentes compostos proteicos presentes nos extratos e picos mais expressivos nas amostras com Citrato-AM e Acetato-AM; e picos isolados para o Citrato-US. Conclui-se que os extratos das folhas da alcachofra com o tampão citrato e acetato atribuíram resultados satisfatórios para atuarem como coagulante vegetal, bem como para realização de novos estudos para purificação de enzimas proteolíticas e aplicação em queijos.
\end{abstract}

Termos para indexação: Métodos de extração; compostos proteicos; cromatografia; análise de componentes principais; Cynara scolymus. 


\section{INTRODUCTION}

The enzymes are usually used in the industries and among the ones that stand out are Hydrolases, with emphasis on carbohydrates, lipases and proteases. Proteases also called peptidases or proteinases are enzymes that hydrolyze the peptide bonds between the amino acids of proteins (Sun et al., 2016). They represent the most important and commercialized class of enzymes in the world, with more than $60 \%$ market share and an annual growth rate of 5.3\% from 2014 to 2019 . In the food industry can be applied as milk coagulants for cheese production, beer production, production of protein hydrolysates, baking industry and manufacture of artificial sweeteners. Proteases are widely distributed among animals, microorganisms and plants and perform important biological functions and physiological processes for living organisms (Fernández-Lucas; Castañeda; Hormigo, 2017).

Coagulation of milk by enzymatic action is a basic step in the manufacture of most cheeses and the addition of rennet or coagulant agents is widely used. Chymosin is the main and oldest enzyme used for the coagulation of milk present in calf rennet and widely applied to cheese production (Esposito et al., 2016; Abebe; Emire, 2020). Enzymes from microbial sources represent an adequate substitute for animal rennet, however there is a reduction in the thermal stability of these enzymes by the application of chemical modifications or by the use of genetic engineering in the microbial organism (Ahmed; Babiker; Mori, 2010; Yegin; Dekker, 2013).

The restrictions of lactovegetarian consumers and for genetically modified foods, as well as religious issues (Islam and Judaism) and changes in eating habits limit the use of animal and microbial rennet (Shah; Mir; Paray, 2014). Besides that, the worldwide increase in cheese processing and the decline in the supply of rennet has led to the search for new proteolytic alternatives of coagulant activity capable of satisfactorily replacing this rennet (Shah; Mir; Paray, 2014; Abebe; Emire, 2020). Trus, increasing attention has been directed toward natural rennet extracted from vegetables with increasing interest in the cheese industry due to its easy availability and simple extraction and purification procedures (Ahmed; Babiker; Mori, 2010).

The species Cynara cardunculus consists of the artichoke. C. cardunculus subsp. scolymus, the cultivated cardoon, C. cardunculus subsp. altilis, and the wild cardoon, C. cardunculus subsp. Sylvestris (Falco et al., 2015).The artichoke Cynara scolymus L. is a perennial herbaceous crop, belonging to the asteraceae family and originated from the Mediterranean basin, where it has been cultivated for thousands of years and diffused all over the world (Falco et al., 2015; Mazzeo et al., 2020). The edible part ("head") of the plant is an immature inflorescence, used as a fresh, frozen or canned food (Mazzeo et al., 2020). Artichoke flowers are mainly used in the production of proteolytic extracts for cheese applications, due to their high plant coagulant activity characteristic of the presence of aspartic proteases in the flowers, known as cardosins and cyprosins (Almeida; Simões, 2018; Llorente et al., 2014). The leaves are more used in herbal extracts due to their beneficial and therapeutic effects (Lattanzio et al., 2009).

The stems and leaves represent about 80 to $85 \%$ of the total fresh weight of the plant and are the most abundant by-products of the artichoke industrial processing that generates large amount of discarded material (Lattanzio et al., 2009). For economic and environmental reasons, adding value to agro-industrial by-products is of great interest. The increase in the search for new sources of plant proteases with high activity and stability is one of the challenges for industrial applications, because the plants have multiple components with different characteristics (Kumari; Sharma; Jagannadham, 2012). Thus, analyzes are needed to assist in the separation and characterization of these compounds.

Among the methods used for protein separation is the High-performance Liquid Chromatography (HPLC), which in addition to versatility has a high analytical capacity. The technique uses a liquid mobile phase responsible for separating the sample components that will flow through a column and providing data on the separation of the compounds (Coskun, 2016; Liu et al., 2020). Often the results obtained during the analyzes are complex and require multivariate techniques to assist in the interpretation of the data. In this sense, Principal Component Analysis (PCA) is a linear pattern recognition method capable of transforming a large number of complex original data into several main components (which are linear combinations of the original variables) and simplify the interpretation of the data through reduction of dimensionality (Sampaio et al., 2017; Teofilović et al., 2017).

There is little information in the literature on the proteolytic study and possibilities of applications in Cynara scolymus leaves extracts and none related to the protein profile. In this sense, the objective of this research was to obtain the extracts from the leaves of the artichoke (Cynara scolymus) in different buffers and methods as an alternative proteolytic source and plant coagulant, as well as the separation and comparison of the protein profile of the extracts by High-performance Liquid Chromatography. 


\section{MATERIAL AND METHODS}

\section{Material and location of the research}

The artichoke (Cynara scolymus) leaves were acquired from the city of São Paulo-SP, Brazil, located in the coordinates of Latitude $23^{\circ} 3256 \mathrm{~S}$ and Longitude $46^{\circ} 38^{\prime} 20^{\prime}$ ' $\mathrm{W}$, in August and September 2020. Cow's milk in local commerce in the city of Itapetinga-BA, Brazil (Latitude $15^{\circ} 15$ ' 23 ' ' $\mathrm{S}$ and Longitude $40^{\circ} 15^{\prime} 27^{\prime}$ ' $\mathrm{W}$ ). All reagents used were from analytical grade and without further purification. Sodium citrate (CAS: 6858-44-2) was acquired from the exodus brand; Sodium acetate (CAS: 6131-904) from the Vetec brand, trichloroacetic acid (CAS: 76-03-9) from Synth; Tris-HCl (CAS: 1185-53-1), bovine serum albumin (CAS: 9048-46-8), tyrosine (CAS: 60-18-4) and Coomassie bright blue G-250 (CAS: 6104-58 - 1), casein (CAS: 9000-71-9) acquired from Sigma-Aldrich Brasil. The experiments were performed at the State University of Southwest Bahia (UESB), campus of Itapetinga, Bahia, Brazil, at the Laboratory of Process Engineering (LPE).

\section{Extracts of artichoke leaf}

The crude extracts of vegetable protein were obtained following the methodology of Esposito et al. (2016), with modifications. Initially, the leaves (1: 5 $\mathrm{m} / \mathrm{v}$ ) went through a pre-treatment where they were incubated in a Shaker incubator (SL 222) $(200 \mathrm{rpm}$, $37{ }^{\circ} \mathrm{C}$ and $20 \mathrm{~min}$ ) in $0.1 \mathrm{M} / \mathrm{pH} 5$ sodium acetate buffer, with $13 \%(\mathrm{w} / \mathrm{v})$ sorbitol. Then, the leaves $(1$ : $3 \mathrm{~m} / \mathrm{v}$ ) passed through the mechanical stirring method (Tecnal-139) at maximum velocity for $3 \mathrm{~min}$ and digital ultrasonic (Soniclean 6) at $35^{\circ} \mathrm{C}$, frequency $40 \mathrm{kHz}$, for $60 \mathrm{~min}$ to assist in the extraction, with three different buffer: $0.1 \mathrm{M}$ sodium citrate / $\mathrm{pH} 3.0$, $0.1 \mathrm{M}$ sodium acetate / $\mathrm{pH} 5.0,0.1 \mathrm{M}$ Tris- $\mathrm{HCl} / \mathrm{pH}$ 7.0. After, the homogenates were filtered in fabric filter and centrifuged (SP-701) at $3248 \mathrm{G}$ for $20 \mathrm{~min}$ at $4{ }^{\circ} \mathrm{C}$. The extracts obtained were stored at $-20{ }^{\circ} \mathrm{C}$ until the analysis. The treatments were performed in triplicate.

\section{Protein determination}

The protein concentration was determined by the Bradford (1976) method using bovine serum albumin (BSA) as a reference standard for the calibration curve. The absorbances of the samples were measured in a scanning UV spectrophotometer (Model Q899UV2) at $595 \mathrm{~nm}$.

\section{Determination of proteolytic and specific activity}

The proteolytic activity (PA) (Equation 1) of the artichoke leaves extracts was determined according to Llorente et al. (2014). Was added $200 \mu \mathrm{L}$ of the crude extract was added in $1 \mathrm{~mL}$ of the $1 \%(\mathrm{w} / \mathrm{v})$ casein solution in 0.1 $\mathrm{M}$ potassium phosphate buffer, $\mathrm{pH}$ 6.0. The reaction was carried out at $37^{\circ} \mathrm{C}$ in a Tecnal thermostatic bath (Model TE-2005) for $10 \mathrm{~min}$ and interrupted by the addition of 1 $\mathrm{mL}$ of $10 \%$ trichloroacetic acid (w/v) and maintained for $20 \mathrm{~min}$ in an ice bath. Subsequently, it was centrifuged (SP701 ) at $3248 \mathrm{~g}$ for $20 \mathrm{~min}$ and the supernatant was collected and its absorbance was read at $280 \mathrm{~nm}$ in a scanning UV spectrophotometer (Model Q899UV2). Unit of enzyme activity was defined as the amount of enzyme needed to produce $1.0 \mu \mathrm{mol} / \mathrm{mL}$ of tyrosine per min.

$P A\left(\frac{U}{m L}\right)=$ Tyrosine $\left(\frac{\mu m o l}{m L}\right) x\left(\frac{\text { Dilution factor }}{\text { Enzyme Volume }}\right) \times\left(\frac{\text { Total Volume }}{\text { Incubation time }}\right)$

The specific enzymatic activity (SEA) was obtained from the ratio between proteolytic activity and protein concentration (Equation 2).

SEA $\left(\frac{U}{m g}\right)=\frac{\text { proteolytic activity }}{\text { Protein }}$

\section{Milk clotting activity and rennet replacement potential}

The milk clotting activity (MCA) (Equation 3) of the artichoke leaves extracts and of Microbial Chymosin (Aspergillus niger var. awamori, HA-LA) was determined by the method described by Arima et al. (1971), with modifications. Cow's milk ( $5 \mathrm{~mL})$ was used as a substrate and incubated at $37^{\circ} \mathrm{C}$ for $5 \mathrm{~min}$ in a Tecnal thermostatic bath (Model TE-2005), then $500 \mu \mathrm{L}$ of crude extract was added. The mixture was kept at $37^{\circ} \mathrm{C}$ until the formation of a visible solid curd, maximum coagulation time of 1 hour. The amount of enzyme that coagulated the substrate in $1 \mathrm{~min}$ was defined as 400 units.

$M C A\left(\frac{U}{m L}\right)=\frac{2400}{\text { Clotting time }(\operatorname{seg})} \times$ Dilution factor

The rennet substitution potential (RSP) (Equation 4) was found by the ratio between milk coagulation activity and protein activity (Afsharnezhad; Shahangian; Sariri, 2019).

$R S P=\frac{\text { Coagulation activity }}{\text { Proteolytic activity }}$ 


\section{High Performance Liquid Chromatography (HPLC) of artichoke leaf extracts}

For the preparation of the samples, the pure extracts of the artichoke leaves were collected and filtered through a $0.44 \mathrm{~mm}$ syringe filter. The methodology used was described by Ong, Henriksson and Shah (2007) with modifications. The samples were subjected to reverse phase liquid chromatography (RP-HPLC) using a C18 column (250x4.6 mm internal diameter, $5 \mathrm{~mm}$ particle size; ZORBAX Eclipse Plus C18), attached to a pre-column (ZORBAX SB-C 18, $4.6 \mathrm{~mm}$ ID $\times 12.5 \mathrm{~mm}, 5 \mu \mathrm{m}$, connected to the system HP Agilent 1260 Infinitty II. Two mobile phases were used, the first (A) composed of an acetonitrile solution $(5 \%, \mathrm{~V} / \mathrm{V})$ and trifluoroacetic acid $(0.1 \%, \mathrm{~V} / \mathrm{V})$ and the second phase (B) formed by acetronitrile $(50 \%, \mathrm{~V} / \mathrm{V})$ and trifluoroacetic acid $(0.1 \%, \mathrm{~V} / \mathrm{V})$. A $20 \mu \mathrm{L}$ aliquot of the sample was automatically injected into the column at a flow rate of $1 \mathrm{~mL} / \mathrm{min}$ as a gradient of the mobile phases $\mathrm{A}$ and $\mathrm{B}$ over 60 minutes. The analysis started with the $100 \%$ flow of mobile phase A and decreased linearly over 60 minutes until $100 \%$ of the flow was represented by phase $\mathrm{B}$. The run temperature was maintained at $30^{\circ} \mathrm{C}$ and the detection of proteins was performed at $280 \mathrm{~nm}$ by Visible Ultraviolet (UV-Vis) with Diode Array Detector (DAD). The protein profile was characterized according to the separation and resolution of the peaks by UV spectra.

\section{Polyacrylamide gel electrophoresis (SDS-PAGE) of artichoke leaf extracts}

The electrophoresis analysis (Model Vert-i10, loccus) in polyacrylamide gel under denaturant conditions (SDS-PAGE) was performed according to the methodology described by Laemmli (1970), with modifications. Extracts of artichoke leaves and denaturant were prepared in the $3: 1(\mathrm{~m} / \mathrm{v})$ proportion and boiled at $100{ }^{\circ} \mathrm{C}$ for $7 \mathrm{~min}$, the separation gel with $12 \%$ concentration and stacking gel at $5 \%$ concentration. The molecular mass standards (Bio-Rad, Hercules, CA, USA) were myosin $(200.0 \mathrm{kDa})$, b-galactosidase $(116.2 \mathrm{kDa})$, phosphorylase $\mathrm{b}(97.4 \mathrm{kDa})$, bovine serum albumin $(66.2$ $\mathrm{kDa})$, ovalbumin $(45.0 \mathrm{kDa})$, carbonic anhydrase $(31.0$ $\mathrm{kDa})$, trypsin inhibitor $(21.5 \mathrm{kDa})$, lysozyme (14.5 kDa, but apparent molecular mass of $15.5 \mathrm{kDa}$ ), and aprotinin $(6.5 \mathrm{kDa})$. Electrophoresis was performed with $40 \mu \mathrm{L}$ of denatured sample per well, run with constant voltage equal to $100 \mathrm{~V}$, for $180 \mathrm{~min}$ and temperature of $4{ }^{\circ} \mathrm{C}$. The gels were stained with Coomassie Brilliant Blue, discolored and scanned.

\section{Statistical analysis}

The results of the analyzes were verified by analysis of variance (ANOVA) and submitted to the test of comparison of means by the Tukey Test, at a significance level of $5 \%$. The statistical analysis was performed using Sisvar statistical software, version 5.6.

Principal Component Analysis (PCA) was applied to HPLC obtained chromatograms of artichoke leaves protein extracts to evaluate the influence of protein extraction methods (mechanical agitation and ultrasound) in order to identify similarities and/or differences in protein profile. In the PCA, the variables used were the maximum absorbance values of the chromatogram peaks and were characterized as vectors. The data were standardized to eliminate the differences between the measurements of the variables to be studied, obtaining a new variable (Z) with mean equal to zero and standard deviation equal to one (Equation 5):

$Z=(X-\mu) / \sigma$

$\mathrm{Z}=$ standardized variable; $\mathrm{X}=$ original variable; $\mu=$ Average e $\sigma=$ standard deviation

From the standardized data the variance and covariance matrix was obtained, which was factored into a diagonal matrix (Santos et al., 2020). The number of main components $(\mathrm{CP})$ was chosen by assessing the cumulative variance which considers the sum of eigenvalues greater than $70 \%$. The scatter plot of the correlation coefficients between the variables and the PCs was plotted to verify the formation of clusters with similar samples. The variables that showed a low correlation $(\mathrm{p}>0.05)$ with the main components were discarded. The Statistical Analysis Syste (SAS) software, Student version and Sigma Plot 11.0 were used.

\section{RESULTS AND DISCUSSION}

\section{Proteins, proteolytic and specific activity of artichoke leaf extracts}

Protein extraction from plant sources is normally performed out from flowers, seeds, roots, rhizomes and leaves, through different aqueous solutions and procedures of maceration and homogenization. The results of protein analysis, proteolytic and specific activity carried out on extracts of artichoke leaf are shown in Table 1.

The protein content found in the artichoke leaf extracts did not present a statistically significant difference 
$(\mathrm{p} \geq 0.05)$ between the buffers used for the method with a mechanical stirrer. However, for the ultrasonic method there was a difference $(\mathrm{p} \leq 0.05)$ of the extract with sodium citrate in relation to the other buffers and lower protein content. It was found that among the methods only the extracts with sodium acetate obtained similar values. Thus, the crude extracts with the best experimental results for proteins among the evaluated methods were Citrate-MS (pH 3.0), sodium acetate ( $\mathrm{pH} 5.0$ ) with both methods, and Tris-US (pH 7), respectively.

Table 1: Mean protein values, proteolytic and specific activity of the extracts obtained from the artichoke leaves by the mechanical and ultrasonic shaker method.

\begin{tabular}{ccc}
\hline \multirow{2}{*}{ Extracts } & Mechanical stirrer & Ultrasonic \\
\cline { 2 - 3 } & \multicolumn{2}{c}{ Proteins $(\mathrm{mg} / \mathrm{mL})$} \\
\hline Citrate & $1.39^{\mathrm{aA}} \pm 0.16$ & $0.73^{\mathrm{aB}} \pm 0.07$ \\
Acetate & $1.31^{\mathrm{aA}} \pm 0.14$ & $1.33^{\mathrm{bA}} \pm 0.02$ \\
Tris & $1.33^{\mathrm{aB}} \pm 0.01$ & $1.42^{\mathrm{bA}} \pm 0.03$ \\
\hline \multicolumn{3}{c}{ Proteolytic activity $(\mathrm{U} / \mathrm{mL})$} \\
\hline Citrate & $13.22^{\mathrm{aB}} \pm 0.15$ & $14.38^{\mathrm{aA}} \pm 0.11$ \\
Acetate & $7.98^{\mathrm{bB}} \pm 0.11$ & $13.04^{\mathrm{bA}} \pm 0.21$ \\
Tris & $8.83^{\mathrm{bA}} \pm 0.68$ & $9.27^{\mathrm{cA}} \pm 0.10$ \\
\hline & \multicolumn{2}{c}{ Specific activity $(\mathrm{U} / \mathrm{mg})$} \\
\hline Citrate & $9.59^{\mathrm{aB}} \pm 1.33$ & $19.71^{\mathrm{aA}} \pm 1.64$ \\
Acetate & $6.12^{\mathrm{bB}} \pm 0.61$ & $9.76^{\mathrm{bA}} \pm 0.21$ \\
Tris & $6.63^{\mathrm{bA}} \pm 0.51$ & $6.53^{\mathrm{cA}} \pm 0.13$ \\
\hline
\end{tabular}

Different lower-case letters in the same columns indicate that they differed between buffers. Different capital letters on the same lines indicate that they differed between methods using the Tukey test to $5 \%$ probability. Mean \pm standard deviation.

The greater predominance of proteolytic and specific activity was found in the Citrate-US samples in relation to the other buffers. The extracts with Tris- $\mathrm{HCl}$ had lower results for these parameters in the ultrasonic method. It can be observed that there was no significant difference $(p \geq 0.05)$ between the samples with sodium acetate and Tris- $\mathrm{HCl}$ in the method with mechanical stirrer. The value for specific activity may be related to the mixture of various proteins in addition to proteases in plant extracts and its increase may be due to the degree of purity of the enzyme (Gutiérrez-Méndez et al., 2019).

Results close to the study were verified in the work of Muthu et al. (2017) for proteins quantification $(0.23 \mathrm{mg} / \mathrm{mL}$ to $1.55 \mathrm{mg} / \mathrm{mL})$ in extracts from 20 leaves of different plant species. They also reported that extracts from Wrightia tincotoria leaves obtained with the sodium acetate (pH 5.0 and 5.5) and Tris- $\mathrm{HCl}$ (7.5) buffers showed the best responses for proteolytic activity. Lomolino, Zannoni and Pierro (2015) evaluated the commercial extract of the Cynara cardunculus L. plant of the same family (Asteraceae) as the artichoke leaves and quantified the protein content $(0.103 \pm 23$ $\mathrm{mg} / \mathrm{mL}$ ). Chávez-Garay et al. (2016) studied the protein content of the extracts with sodium acetate buffer $(\mathrm{pH}$ 5.0) of the Solanum elaeagnifolium plant and obtained values for the fruits $(1.55 \mathrm{mg} / \mathrm{mL})$, peel $(1.06 \mathrm{mg} / \mathrm{mL})$ and seeds $(1.59 \mathrm{mg} / \mathrm{mL})$; and Gutiérrez-Méndez et al. (2019) found specific proteolytic activity $0.78 \mathrm{U} / \mathrm{mg}$ for the same plant extract.

Results of the characterization of extracts from the artichoke flowers were demonstrated by Gomes et al. (2019) when studying extracts of 15 Cynara cardunculus $L$. flowers with proteolytic activity ranging from 4.10 to $5.28 \%$ and 3.63 to $5.07 \%$. Lower values of the analyzes with extracts of the artichoke leaves were demonstrated by Llorente, Brutti and Caffini (2004) when determining the protein content $(0.34,0.28$ and $0.13 \mathrm{mg} / \mathrm{mL})$ and proteolytic activities $(0.50,2.39$ and $1.10 \mathrm{U} / \mathrm{mg})$ of the raw extracts of the artichoke leaves with use of electric mixer. Bueno-Gavilá et al. (2020) described that the proteolytic activity of the artichoke flower extracts was influenced by the buffer used, with greater activity $(62 \%)$ in sodium citrate at $\mathrm{pH}$ 5.0.

In general, the parameters evaluated in this study with extracts of artichoke (Cynara scolymus) leaves obtained good results with the use of pretreatment, together with sodium citrate $\mathrm{pH} 3.0$, sodium acetate $\mathrm{pH}$ 5.0 and Tris- $\mathrm{Hcl} \mathrm{pH} 7.0$ buffers and mechanical stirring and ultrasonic methods. The pretreatment aided in the rupture of the rigid cell wall of cellulose, hemicelluloses, lignin and complex polysaccharides, even without the addition of viscosima as previously reported by Esposito et al. (2016). The extraction was based on the work of Esposito et al. (2016) with artichoke leaves extracts using a different method (ultra-turrax). The extract with Citrate-US obtained better experimental result that can be related to most aspartic proteases that are activated at acidic $\mathrm{pH}$ during the cheese making process for example (Llorente et al., 2014).

\section{Coagulation activity and rennet substitution potential of artichoke leaf extracts}

Vegetables contain a wide variety of proteins in their tissues because of their properties and functions. 
Factors such as temperature, $\mathrm{pH}$ and the type of protease present in crude vegetable extracts affect the determination of milk clotting activity (MazorraManzano et al., 2013) and consequently its potential for replacing rennet. The results of milk clotting activity (MCA) and rennet substitution potential (RSP) of the artichoke (Cynara scolymus) leaves extracts are shown in Table 2.

It can be observed that the extract of the artichoke leaves with sodium citrate $(\mathrm{pH} 3.0)$ in the ultrasonic method exhibited the best effect in the MCA, a measure of concentration of enzymes for coagulation and an important parameter in the production of cheeses, with maximum duration of $1 \mathrm{~min}$. The other extracts obtained with citrate and acetate had similar results for MCA due to the coagulation time being close and although the values were lower than the extract with Citrate-US the coagulation was obtained in a period considered fast. The extracts performed with Tris- $\mathrm{HCl}$ were not coagulated in the maximum period studied (1 hour).

According to Llorente et al. (2014) and Amira et al. (2017) the vegetable enzymes for milk coagulation that are generally used belong to the class of aspartic proteases (as from example the artichoke), that are successful in causing specific hydrolysis at the Phe105Met106 bond of the $\kappa$-casein $\mathrm{C}$-terminal, and the vast majority of these proteases are activated at acidic $\mathrm{pH}$. With the results found in the study it also be seen that the methods used for the production of the extracts directly influenced the extraction of coagulant enzymes together with the chosen buffer.

The extract with Citrate-US obtained the highest RSP among other buffers and methods, followed by the extract with Acetate-MS. The substitution potential of vegetable rennet is an important parameter in the possibility of proteases to form curd and replace animal rennet. The high milk coagulation capacity and relatively low proteolytic activity attribute the enzyme to a high ratio between MCA and PA. The higher the RSP value, the better the use of the coagulant for cheese production, since the coagulation time is short and the volume of coagulant required is low (Horne; Banks, 2004; Yadav; Patel; Jagannadham 2012; Gutiérrez-Méndez et al., 2019).

Commercial chymosine MCA was performed as a comparison parameter with the extracts studied from the artichoke leaf and also PA to obtain the RSP result. Chymosin presented PA of $25.150 .031 \mathrm{U} / \mathrm{mL}$ and significant difference for MCA and RSP in relation to the extracts. Even so, the coagulation time of the treatments that coagulated did not exceed $3 \mathrm{~min}$. Chymosin has been considered the most efficient coagulant due to the higher value for MCA and pepsin as an adequate alternative, even with lower values. These two enzymes of animal origin were identified in the work of Afsharnezhad, Shahangian and Sariri (2019) with results for MCA and RSP of chymosin of $81 \mathrm{U} / \mathrm{mL}$ and 522.58 and pepsin 53 $\mathrm{U} / \mathrm{mL}$ and 19.13 . The values presented for MCA were lower than the study with extracts of artichoke leaves by different treatments. The chymosin RSP was superior to extracts and pepsin close to the study.

\section{High-Performance Liquid Chromatography (HPLC)}

The chromatographic conditions used by the HPLC method proved to be suitable for separating the different compounds present in the artichoke leaves extracts (Figure 1). The profiles of the extracts were obtained in order to evaluate the effect of the variables (buffers and extraction methods) before the compounds present in the extracts.

Table 2: Coagulation activity of artichoke leaf extracts in cow's milk and its rennet potential for curd replacement.

\begin{tabular}{ccccccc}
\hline \multirow{2}{*}{ Extracts } & \multicolumn{3}{c}{ Mechanical stirrer } & \multicolumn{3}{c}{ Ultrasonic } \\
\cline { 2 - 7 } & Time $(\mathrm{sec})$ & $\mathrm{MCA}(\mathrm{U} / \mathrm{mL})$ & MCA/PA & Time $(\mathrm{sec})$ & MCA $(\mathrm{U} / \mathrm{mL})$ & $\mathrm{MCA} / \mathrm{PA}$ \\
\hline Citrate & 174 & $151.72^{\mathrm{aB}} \pm 0.00$ & 11.48 & 60 & $440.00^{\mathrm{aA}} \pm 0.00$ & 30.60 \\
Acetate & 180 & $146.67^{\mathrm{aB}} \pm 0.00$ & 18.38 & 180 & $146.67^{\mathrm{bB}} \pm 0.00$ & 11.25 \\
Tris & $\mathrm{NS}$ & $\mathrm{NS}$ & $\mathrm{NS}$ & $\mathrm{NS}$ & $\mathrm{NS}$ & $\mathrm{NS}$ \\
\hline Coagulant & \multicolumn{2}{c}{ Time $(\mathrm{sec})$} & \multicolumn{2}{c}{$\mathrm{MCA}(\mathrm{U} / \mathrm{mL})$} & $\mathrm{MCA} / \mathrm{PA}$ \\
Chymosin & \multicolumn{2}{c}{37} & \multicolumn{2}{c}{$713.51^{\mathrm{bC}} \pm 0.00$} & 38.25 \\
\hline
\end{tabular}

Different lower case letters in the same columns indicate that they differed between buffers and chymosin. Different capital letters on the same lines indicate that they differed between methods using the Tukey test to $5 \%$ probability. Mean \pm standard deviation. NS: Milk clotting activity not specified. 


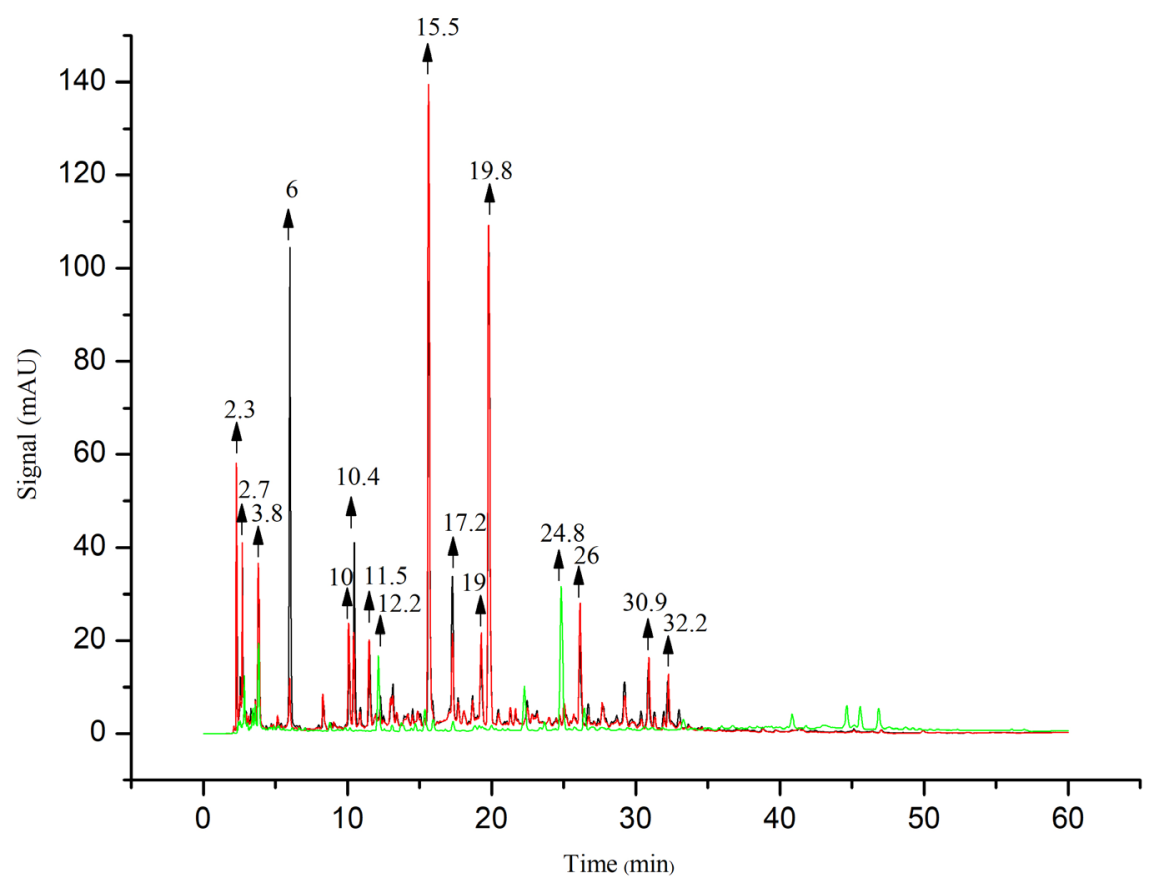

Figure 1: HPLC chromatogram of protein extracts from artichoke leaves using the mechanical stirring method. Citrate-MS (black), Acetate-MS (red) and Tris-MS (green).

The effects of treatments on the elution profiles were marked by chromatographic peaks at 0 to $50 \mathrm{~min}$. The spectra showed that the areas of the chromatograms for the extracts obtained with Citrate-MS and Acetate-MS buffers showed better sensitivity and more predominant peaks. This result reveals that some biomolecules were extracted more efficiently at acidic $\mathrm{pH}$. According to Yegin and Dekker (2013) some proteins have residues of aspartic acid in their active sites that can be optimally activated at acidic $\mathrm{pH}$, which possibly may have favored the extraction of these compounds.

According to the retention times and UV spectra of the main peaks of the chromatograms, similarities were observed between the compounds found in the extracts with Citrate-MS, Acetate-MS and Tris-MS in the interval between 2 to $4 \mathrm{~min}$, with difference in peak intensity. The extract with Acetate-MS was particularly the buffer that showed the highest peak intensity ranging from 36 to $58 \mathrm{mAU}$, compared to the other extracts with Citrate-MS (28 to $37 \mathrm{mAU}$ ) and Tris-MS (12 to $19.5 \mathrm{mAU}$ ). Srivastava et al. (2009) identified the presence of alkaline protease activity from spinach leaves by HPLC at $280 \mathrm{~nm}$ with less intense peaks in 2 to $4 \mathrm{~min}$ and predominantly in 7 to $9 \mathrm{~min}$. It is important to note that the observed peaks can vary, as they are easily affected by experimental extraction parameters, type of sample, origin and plant conditions (Lombardo et al., 2010).
An individual peak with high intensity (104 mAU) was detected only for the extract with Citrate-MS buffer in the elution time of $6 \mathrm{~min}$, possibly due to the presence of some compound that was not identified in the other extracts. Another particular peak was identified by the extract with buffer Acetate-MS in time $(11.50 \mathrm{~min})$ relatively short and intensity $20.73 \mathrm{mAU}$, indicates that the affinity for the hydrophobic stationary phase is low and therefore the compound has a hydrophilic character. From this, the relationship of this hydrophobicity is possible to characterize it with the presence of amino acids, such as glutamic acid (Afsharnezhad; Shahangian; Sariri 2019).

The analysis identified other relevant peaks in fractions eluted at retention times of approximately 10, 15, 17,19 and 26 min similar for the extracts with the CitrateMS buffer (40.76; 97.40; 34.39; 107.54 and 19.10) mAU and Acetate-MS (28.85; 139.72; 21.61;109.30 and 27.83) mAU, respectively. For the extract with Tris-MS, only the times in 15.5 and 26 min showed signs of presence of compounds, however with low intensity peaks compared to the other extracts (5.26 and $5.58 \mathrm{mAU}$ ). However, the Tris-MS extract showed an individual peak in $24 \mathrm{~min}$ (31.7 mAU). After that time, the extract with AcetateMS buffer showed an elution profile in $30 \mathrm{~min}$ (16.39 $\mathrm{mAU}$ ) and $32 \mathrm{~min}$ (13.27 mAU). Veríssimo et al. (1996) characterized aspartic proteinases in fresh flower extracts 
from Cynara cardunculus $L$. and was able to identify peaks of polypeptide chains constituting cardosin-A in 25 to $30 \mathrm{~min}$ and cardosin-B in 23 to $30 \mathrm{~min}$ using the same method (RP-HPLC) and column $(\mathrm{C} 18)$ and gradient used of $20-80 \%$ acetonitrile in $40 \mathrm{~min}$.

The characterization of proteins in plant extracts by the RP-HPLC method under conditions similar to those of the study was discussed by some authors to evaluate the efficiency of the purification of proteases (Wang et al., 2020). According to the authors some factors such as the properties of the mobile phase can affect the activity of the protease, however, in these conditions evaluated it was possible to show the effectiveness of the method and to identify peaks related to milk-clotting proteases, which were consistent with SDS-PAGE results.

The chromatographic profile in HPLC obtained by reading samples of artichoke leaves extracts extracted with different buffers and by the ultrasonic method is shown in Figure 2. The extracts maintained a well-distributed profile during the analysis, identified by peaks with a variety of compounds.

According to Figure 2, the elution profile for the ultrasound method revealed bands in the first moments of analysis (0-5 min). The extraction method favored the peak intensity in this time interval for the Tris-US extract, with intensity ranging from 12 to $76 \mathrm{mAU}$ compared to that found in mechanical agitation. However, the compounds possibly separated in the same time interval showed to be more sensitive to the action of the extract with AcetateUS (42 to $76 \mathrm{mAU}$ ) and peaks with less intensity for the Citrate-US buffer (6 to $7 \mathrm{mAU}$ ). The extract with AcetateUS buffer identified a particular peak in the elution time of $8.8 \mathrm{~min}$. It also presented other individual peaks for this method compared to Citrate-US and Tris-US at the retention times of $26.4 \mathrm{~min}$ (10.45 $\mathrm{mAU})$ and $33 \mathrm{~min}$ (10 $\mathrm{mAU}$ ), similar to the compounds that were separated in the same time range with the mechanical stirrer method.

The extract with Citrate-US buffer showed isolated peaks in $10.7 ; 23.5$ and $33.7 \mathrm{~min}$ that represent compounds that were not detected for the other extracts. The results revealed similar peaks for extracts with Acetate-US and Tris-US buffers in 12, 15, 24.7 and $40.8 \mathrm{~min}$, however Acetate-US detected peaks with greater intensities. The elution time of $24.7 \mathrm{~min}$ of the Tris-US extract showed higher intensity (52.04 mAU) than the extract with TrisMS (31.7 mAU). As shown by Veríssimo et al. (1995) these peaks have the potential to indicate the presence of active enzymes of aspartic proteases (cardosins A and B) that may be related to the results found for proteolytic activity in the studied extracts, since these enzymes have proteolytic action on caseins being the its activity similar to animal rennet.

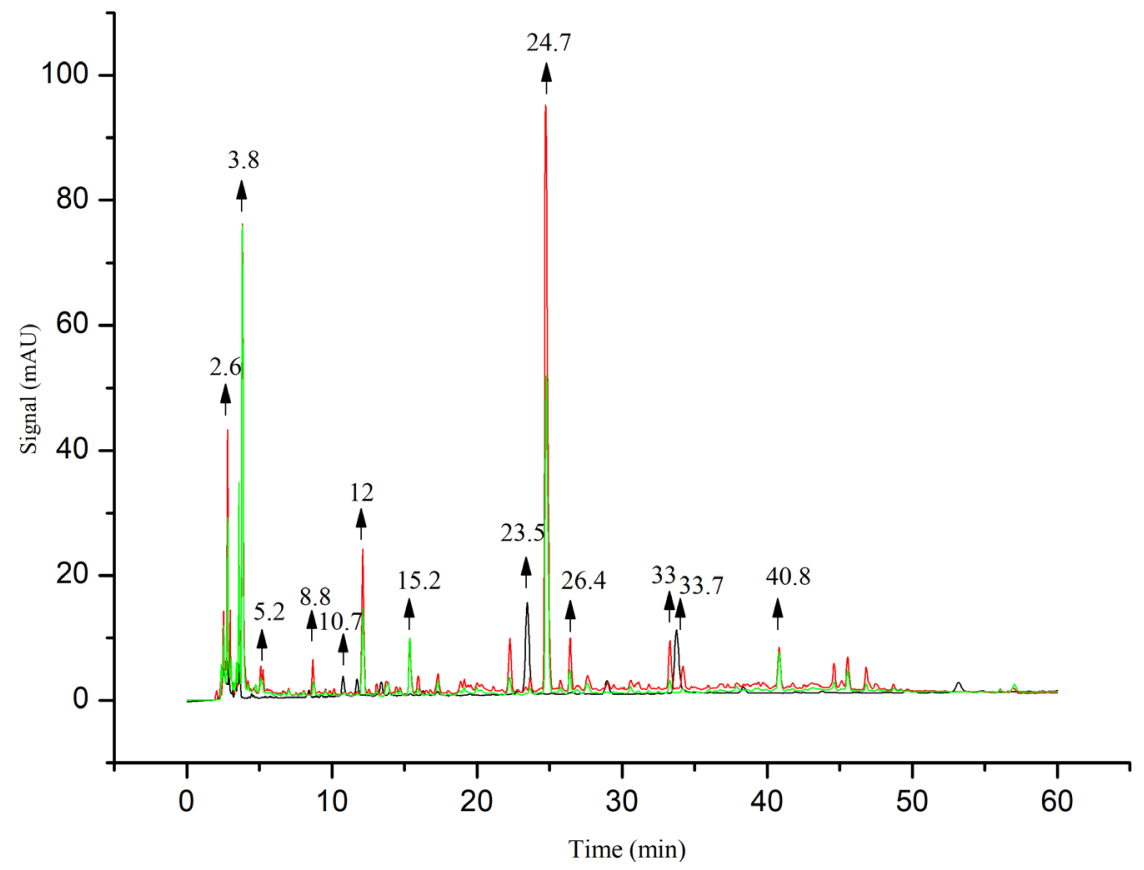

Figure 2: HPLC chromatogram of extracts of protein from artichoke leaves using the ultrasound method. CitrateUS (black), Acetate-US (red) and Tris-US (green). 
A study of the chromatographic profile of the leaf extract of Cynara scolymus.L. by RP-HPLC showed similarities with the UV spectra in some of the peaks highlighted in the present study (Souza et al., 2018). The applied extraction methods may have influenced for a better resolution of the peaks of the compounds present in the extracts due to the good selectivity presented in the analyzed chromatograms

With the results of the chromatographic evaluation (HPLC) of the protein extracts of the artichoke leaves it was possible to compare the protein profile of various proteins. Most of the signal intensities observed in the extract chromatograms revealed that the more acidic buffers in the $\mathrm{pH}$ range may have favored the presence of these compounds, regardless of the extraction procedure, but the peak intensities by the mechanical stirring method were more intense.

\section{Polyacrylamide gel electrophoresis (SDS-PAGE) of artichoke leaf extracts}

To verify the presence of proteins in the artichoke leaves extracts with different extraction methods and buffers, electrophoresis analysis was performed, as shown in Figure 3. The molecular marker bands used as standard were from 6.5 to $200 \mathrm{kDa}$. It can be verified that the extracts with Acetate and Tris-Hcl presented greater predominance of proteins with molecular mass around 21.5 $\mathrm{kDa}$ and $31 \mathrm{kDa}$; and other two weaker bands between $6.5 \mathrm{kDa}$ and $15.5 \mathrm{kDa}$. The extract of Citrate-MS showed the presence of proteins between $15.5 \mathrm{kDa}$ to $21.5 \mathrm{kDa}$ and below $31 \mathrm{kDa}$. All the extracts obtained proteins of molecular mass of $200 \mathrm{kDa}$. The protein bands with better visibility in the electrophoresis analysis of artichoke leaves extracts are directly related to the peaks of greater intensity in the chromatography (Figures 1 and 2).

Studies in the literature have proven the presence of proteins in plants of the family Ascareacea. Ordiales et al. (2016) have studied the protein profile of Cynara cardunculus L. extracts and found intense bands in 16.7 and $30.2 \mathrm{kDa}$ and 13.5 and $32 \mathrm{kDa}$ that could indicate cardosin $\mathrm{A}$ and cardosin B, respectively. Llorente et al. (2004) performed the purification of Cynara Scolymus aspartic protease, identified the $31 \mathrm{kDa}$ molar mass as cardosin and confirmed it in mass spectrometry. According to Veríssimo et al. (1996) cardosin A and $B$ was distinguished by means of relative mobility in SDS-PAGE gels. Both are heterodimeric, being composed of two dissimilar polypeptide subunits, with molecular masses of 31 and $15 \mathrm{kDa}$ and 34 and $14 \mathrm{kDa}$, respectively. Amira et al. (2017) evaluated the electrophoretic profile (SDS-PAGE) of the raw extracts of the thistle flowers (Cynara cardunculus L.) and determined that the intensity of the protein band 30 $\mathrm{kDa}$ is related to milk coagulation.

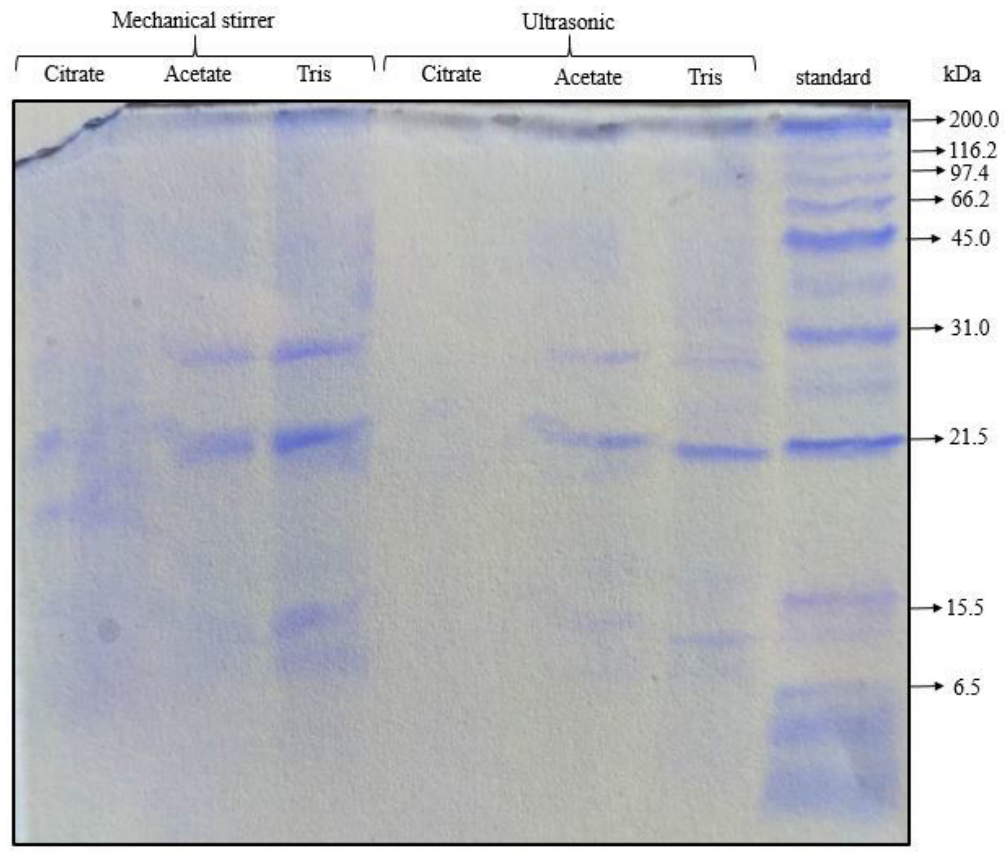

Figure 3: Electrophoretic profile (SDS-PAGE) of the artichoke leaves extracts, (1) Citrate-AM; (2) Acetate-AM; (3) Tris-AM ; (4) Citrate-US; (5) Acetate-US; (6) Tris-US. (P) molecular protein marker (6.5 to 200 kDa). 


\section{Principal Component Analysis (PCA)}

Principal Component Analysis (PCA) was applied to chromatograms of protein extracts obtained by HPLC in order to evaluate the influence of extraction methods (mechanical agitation and ultrasound) on sample separation. The differences observed in relation to the intensities and varieties of the peaks indicate the presence of many protein compounds in extracts. The PCA allowed us to evaluate the set of variables (proteinrelated absorbance values) responsible for grouping samples. The absorbance data (19 peaks) were collected, standardized and submitted to analysis. After discarding the non-significant variables, ten peaks were analyzed and the percentage of explanation of the main components was increased.

The variability of the data was explained by two main components that were responsible for $93.47 \%$ of the total variation, indicating that the observed peaks allowed to satisfactorily separate the samples based on their similarities and / or differences. Principal component I (PC1) explained $70.09 \%$ of the data variation and showed a significant correlation $(p<0.05)$ with seven of the ten variables (peaks) observed represented by the retention times (in minutes): $2.3 ; 10.5 ; 15.5 ; 17 ; 19 ; 26$ and 30. Principal component II (PC2) was responsible for $23,38 \%$ and correlated with three other variables $(3.7 ; 11.5$ and $23.5 \mathrm{~min}$ ). The latter components were associated with a smaller portion of the available variance. According to Teofilović et al. (2017), the main components are chosen so that (PC1) accounts for the greatest variability of the data, followed by PC2 and so on.

When analyzing Figure 4, we observe a group of samples located to the right of PC1 (positive part of the graph) related to the protein extracts obtained by mechanical stirring (MS) and another group to the left of PC1 (negative part of the graph), associated to extracts obtained by ultrasound (US). The extracts obtained from Tris-MS showed different dispersion behavior.

The method of mechanical agitation (MS) allowed to observe that the treatments (Citrate-MS and AcetateMS) showed similarities in relation to the proteins found in the extracts, being grouped in the positive part of CP1. This indicates higher amount of protein compounds extracted compared to samples with negative CP1 values. When using this method, the peaks $(10.5 ; 15.5 ; 19 ; 26$ minutes) were identified in the extracts Citrate-MS and Acetate-MS representing descriptors of importance correlated with CP1. The Tris-MS extract was located on the negative side of $\mathrm{CP} 1$ and $\mathrm{CP} 2$ for presenting peaks with lower intensities in the HPLC analysis, which can be associated with the characteristics of the buffer and its interactions with the molecules when using the mechanical stirrer showing reduction or absence of protein compounds associated with $\mathrm{CP} 1$ and grouping close to ultrasound treatments. The study also showed lower results for Tris-MS in relation to protein content, in addition to not showing milk clotting activity.

The graph (PCA) showed that the protein extracts obtained by ultrasound were grouped to the left of PC1. It is observed that the main component II (CP2) was responsible for the separation of data, and the variables (3.7; 11.5 and $23.5 \mathrm{~min}$ ) being positively correlated with CP2. The results of the chromatography for the ultrasound method allowed to observe that during the first five minutes of analysis, the extracts (Acetate-US and Tris-US) showed peaks with high intensity, whereas Citrate-US provided less intense peaks. Other peaks $(12,15,24$ and $40 \mathrm{~min}$ ) were also identified for Acetate-US and Tris-US, facilitating the grouping due to the similarities in the extract composition.

However, Citrate-US treatment showed isolated peaks at times of 11 and 23.5 minutes, representing proteins that were not detected in the other extracts. It is possible that these peaks are related to proteolytic activity, because when analyzing the graph it is observed that Citrate-US, although it did not present a higher protein content, obtained statistically superior results in relation to specific and proteolytic activity, which may be related the presence of the proteins of interest. The amount of protein compounds extracted by CitrateUS was lower, as it had a low concentration of the peaks associated with CP1. In this sense, the distance between the samples may be related to differences in the composition of the extracts, displacing the Citrate-US to the negative side of CP2.

Among the buffers evaluated in the study, both citrate and acetate showed good results for milk coagulation capacity (MCA) and rennet substitution potential (RSP). In a study by Esposito et al. (2016), extracts of artichoke leaves and alpine thistle flowers were evaluated using the same extraction buffers at different $\mathrm{pH}$. It was possible to extract two milk coagulation enzymes belonging to the aspartic protease family, where the Citrate buffer provided better yield with a $\mathrm{pH}$ value (5.0) similar to that used in the coagulation of milk during cheese processing. Among the methods evaluated in this study, ultrasound was the most suitable for obtaining proteases from extracts of artichoke leaves. 


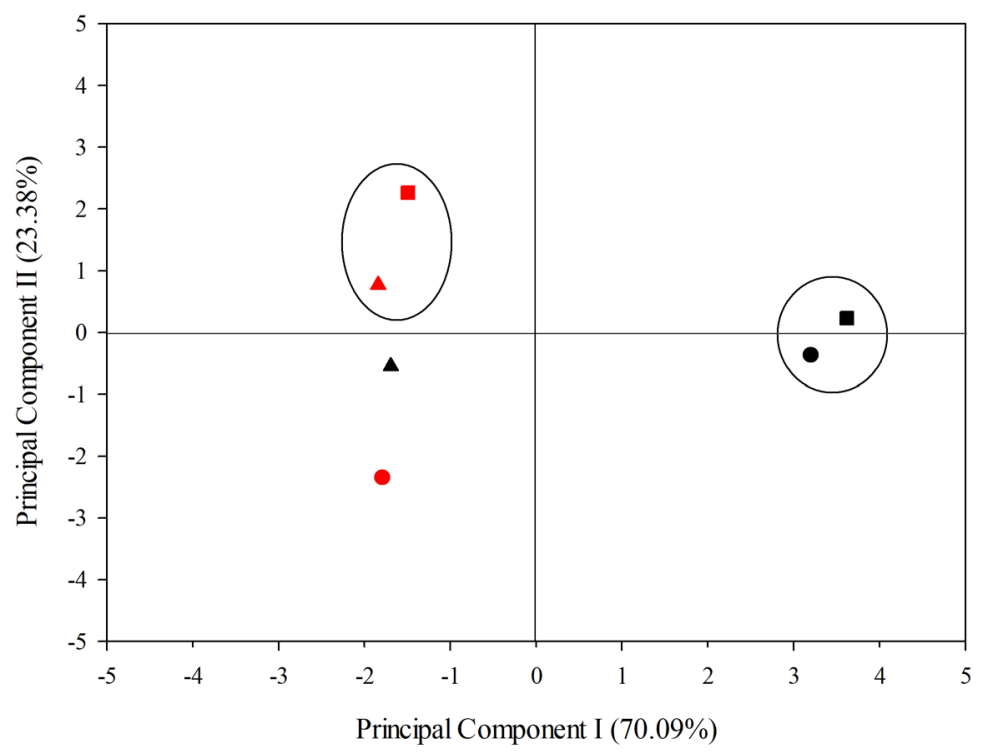

Figure 4: Scatter plot of Principal Components 1 and 2 of protein extracts from Artichoke leaves by the method of mechanical agitation and ultrasound according to the data obtained by HPLC. Black symbols: Mechanical extraction; Red symbols: Extraction by ultrasound. The distinct geometry of the symbols represents the different plugs used in the extraction.

Citrate-MS, $\mathbf{a}$ Acetate-MS, $\mathbf{\Delta}$ Tris-MS, Citrate-US, aAcetate-US and $\mathbf{\Delta}$ Tris-US.

Chromatograms obtained using HPLC had a significant impact on sample separation. Some compounds were eluted in longer times (26 and 45 minutes) and the ultrasound method allowed to observe these peaks with higher intensity, which indicates the possible extraction of components with greater hydrophobicity due to the longer retention times. Balaraman and Rathnasamy (2019), when evaluating the factors that most influenced the extraction yield of proteases obtained by ultrasound, found that the analysis time and temperature stood out. Many factors can alter the protein extraction process, that is why it is important to optimize the extraction conditions in order to improve the characteristics of the desired product.

The PCA allowed the formation of groups of samples according to the extraction method used. In the mechanical stirring method, both Citrate-MS and Acetate-MS could be indicated to obtain protein extracts from artichoke leaves. However, according to the results of the analysis carried out in this study, the extract obtained with sodium citrate associated with the ultrasound presented relevant results and can be chosen for application in cheeses as a plant source coagulant.

\section{CONCLUSIONS}

Extract of the artichoke leaves with Citrate-MS presented lower protein content and the Citratro-US the best responses in relation to other treatments for the parameters of proteolytic activity, specific, milk coagulation and rennet replacement potential. HPLC analysis of artichoke leaves extracts revealed different protein profiles between the buffers and extraction methods used. The peak resolutions were more expressive in the extracts obtained with Citrate-MS and Acetate-MS. Protein confirmation was verified in the electrophoresis analysis. Principal Component Analysis showed that artichoke leaves extracts can be separated according to the extraction method used due to differences in protein profile, in addition to checking the applicability of the HPLC technique for separating the components present in the extracts. This research presents the potential of using the by-product (leaves) of artichoke as a new source of proteolytic plant coagulant studied in Brazil under different extraction methods. Another scientific novelty of this article is the protein chromatographic profile of extracts, the PCA applied to HPLC analysis in the field of plant proteases and the confirmation of proteins by 
electrophoresis. Thus, it is feasible to develop research with the purification of proteolytic enzymes from the leaves of the artichoke and application in the food area as a vegetable coagulant.

\section{ACKNOWLEDGMENTS}

We would like to thank the Coordination for the Improvement of Higher Education Personnel (CAPES) for the financial support and research grants provided.

\section{REFERENCES}

ABEBE, B.; EMIRE, S. Manufacture of fresh cheese using east African Calotropis procera leaves extract crude enzyme as milk coagulant. Food Science and Nutrition, 8(9):48314842, 2020.

AFSHARNEZHAD, M.; SHAHANGIAN, S. S.; SARIRI, R. A novel milk-clotting cysteine protease from Ficus johannis: Purification and characterization. International Journal of Biological Macromolecules, 121(1):173-182, 2019.

AHMED, M. I. A.; BABIKER, E. E.; MORI, N. pH stability and influence of salts on activity of a milk-clotting enzyme from Solanum dubium seeds and its enzymatic action on bovine caseins. LWT - Food Science and Technology, 43(5):759-764, 2010.

ALMEIDA, C. M.; SIMÕES, I. Cardoon-based rennets for cheese production. Applied Microbiology and Biotechnology, 102(11):4675-4686, 2018.

AMIRA, B. A. et al. Milk-clotting properties of plant rennets and their enzymatic, rheological, and sensory role in cheese making: A review. International Journal of Food Properties, 20(1):S7-S93, 2017.

ARIMA, K. et al. Milk-clotting enzyme from microorganisms. Agricultural and Biological Chemistry, 35(9):1398-1401, 1971.

BALARAMAN, H. B.; RATHNASAMY, S. K. Selective purification of protease from ginger and sodom apple by ultrasound assisted liquid-liquid microextraction using natural deep eutectic solvent. Microchemical Journal, 150:e104132, 2019.

BRADFORD, M. M. A rapid and sensitive method for quantitation of microgram quantities of protein utilizing the principle of protein- dye binding. Analytical Biochemistry, 72(12):248-254, 1976.
BUENO-GAVILÁ, E. et al. Characterization of proteolytic activity of artichoke (Cynara scolymus L.) flower extracts on bovine casein to obtain bioactive peptides. Animals, 10(5):1-11, 2020.

CHÁVEZ-GARAY, D. R. et al. Partial characterization of a plant coagulant obtained from the berries of Solanum elaeagnifolium. CутA - Journal of Food, 14(2):200-205, 2016.

COSKUN, O. Separation tecniques: Chromatography. Northern Clinics of Istanbul, 3(2):156-160, 2016.

ESPOSITO, M. et al. Enzymatic milk clotting activity in artichoke (Cynara scolymus) leaves and alpine thistle (Carduus defloratus) flowers. Immobilization of alpine thistle aspartic protease. Food Chemistry, 204:115121, 2016.

FALCO, B. et al. Artichoke: Botanical, agronomical, phytochemical, and pharmacological overview. Phytochemistry Reviews, 14(6):993-1018, 2015.

FERNÁNDEZ-LUCAS, J.; CASTAÑEDA, D.; HORMIGO, D. New trends for a classical enzyme: Papain, a biotechnological success story in the food industry. Trends in Food Science and Technology, 68(10):91-101, 2017.

GOMES, S. et al. Characterization of Cynara cardunculus $L$. flower from Alentejo as a coagulant agent for cheesemaking. International Dairy Journal, 91:178184, 2019.

GUTIÉRREZ-MÉNDEZ, N. et al. Proteolysis and rheological properties of cream cheese made with a plant-derived coagulant from Solanum elaeagnifolium. Foods, 8(2):44, 2019.

HORNE, D. S.; BANKS, J. M. Rennet-induced coagulation of milk. In: McSWEENEY, P. L. et al. Cheese chemistry, physics and microbiology. Amsterdam, Netherlands: Elsevier Applied Science, v.1, p.47-70, 2004.

KUMARI, M.; SHARMA, A.; JAGANNADHAM, M. V. Religiosin B, a milk-clotting serine protease from Ficus religiosa. Food Chemistry, 131(4):1295-1303, 2012.

LAEMMLI, U. K. Cleavage of structural proteins during the assembly of the head of bacteriophage T4. Nature, 227:680-685, 1970.

LATTANZIO, V. et al. Globe artichoke: A functional food and source of nutraceutical ingredients. Journal of Functional Foods, 1(2):131-144, 2009. 
LIU, S. et al. Recent advances on protein separation and purification methods. Advances in Colloid and Interface Science, 284:e102254, 2020.

LLORENTE, B. E. et al. Use of artichoke (Cynara scolymus) flower extract as a substitute for bovine rennet in the manufacture of gouda-type cheese: Characterization of aspartic proteases. Food Chemistry, 159:55-63, 2014.

LLORENTE, B. E.; BRUTTI, C. B.; CAFFINI, N. O. Purification and characterization of a milk-clotting aspartic proteinase from globe artichoke (Cynara scolymus L.). Journal of Agricultural and Food Chemistry, 52(26):8182-8189, 2004.

LOMBARDO, S. et al. Influence of genotype, harvest time and plant part on polyphenolic composition of globe artichoke [Cynara cardunculus L. var. scolymus (L.) Fiori]. Food Chemistry, 119(3):1175-1181, 2010.

LOMOLINO, G.; ZANNONI, S.; PIERRO, G. D. Characterization of crude esterase activity from two plants used in cheese making: Cynara cardunculus L. and Ficus carica L. Food Biotechnology, 29(4):1532-4249, 2015.

MAZORRA-MANZANO, M. A. et al. Sour orange Citrus aurantium L. flowers: A new vegetable source ofmilk-clotting proteases. LWT - Food Science and Technology, 54(2):325$330,2013$.

MAZZEO, G. et al. Insect pollinators improve seed production in globe artichoke (Cynara cardunculus var. scolymus). Annals of Applied Biology, 176(3):241-248, 2020.

MUTHU, S. et al. Antibacterial serine protease from Wrightia tinctoria: Purification and characterization. Plant Physiology and Biochemistry, 112:161-172, 2017.

ONG, L.; ENRIKSSON, A.; SHAH, N. P. Original article angiotensin converting enzyme-inhibitory activity in cheddar cheeses made with the addition of probiotic Lactobacillus casei sp. Dairy Science and Technology, 87(2):149-165, 2007.

ORDIALES, E. et al. Characterisation of the vegetable rennets used for 'Torta del Casar' cheese making by a protein profile method. The International Journal of Dairy Technology, 69(2):272-281, 2016.

SAMPAIO, P. et al. Dataset of near-infrared spectroscopy measurement for amylose determination using PLS algorithms. Data in Brief, 15:389-396, 2017.

SANTOS, M. P. F. et al. New insight about the relationship between the main characteristics of precursor materials and activated carbon properties using multivariate analysis. Canadian Journal of Chemical Engineering, 98(7):15011511, 2020.

SHAH, M. A.; MIR, S. A.; PARAY, M. A. Plant proteases as milkclotting enzymes in cheesemaking: A review. Dairy Science and Technology, 94(1):5-16, 2014.

SOUZA, O. A. et al. Fingerprinting Cynara scolymus L . (Artichoke) by means of a green statistically developed HPLC-PAD method. Food Analytical Methods, 11:19771985, 2018.

SRIVASTAVA, A. K. et al. Purification and characterization of a salinity induced alkaline protease from isolated spinach chloroplasts. Acta Physiologiae Plantarum, 31(1):187197, 2009.

SUN, Q. et al. Comparative analysis on the distribution of protease activities among fruits and vegetable resources. Food Chemistry, 213:708-713, 2016.

TEOFILOVIĆ, B. et al. Experimental and chemometric study of antioxidant capacity of basil (Ocimum basilicum) extracts. Industrial Crops and Products, 100:176$182,2017$.

VERÍSSIMO, P. et al. The vegetable rennet of Cynara cardunculus L. contains two proteinases with chymosin and pepsin-like specificities. Biotechnology Letters, 17(6):621-626, 1995.

VERÍSSIMO, P. et al. Purification, characterization and partial amino acid sequencing of two new aspartic proteinases from fresh flowers of Cynara cardunculus L. European Journal of Biochemistry, 235(3):762-768, 1996.

WANG, X. et al. Label-free quantitative proteomic analysis of the biological functions of Moringa oleifera seed proteins provides insights regarding the milk- clotting proteases. International Journal of Biological Macromolecules, 144:325-333, 2020.

YADAV, R. P.; PATEL, A. K.; JAGANNADHAM, M. V. Neriifolin $S$, a dimeric serine protease from Euphorbia neriifolia Linn.: Purification and biochemical characterisation. Food Chemistry, 132(3):1296-1304, 2012.

YEGIN, S.; DEKKER, P. Progress in the field of aspartic proteinases in cheese manufacturing: Structures, functions, catalytic mechanism, inhibition, and engineering. Dairy Science and Technology, 93(6):565594, 2013. 